\title{
Editorial \\ Eating Disorders in the Era of the COVID-19 Pandemic: What Have We Learned?
}

\author{
Palmiero Monteleone
}

check for updates

Citation: Monteleone, P. Eating Disorders in the Era of the COVID-19 Pandemic: What Have We Learned? Int. J. Environ. Res. Public Health 2021, 18, 12381. https://doi.org/10.3390/ ijerph182312381

Received: 15 November 2021 Accepted: 23 November 2021 Published: 25 November 2021

Publisher's Note: MDPI stays neutral with regard to jurisdictional claims in published maps and institutional affiliations.

Copyright: (C) 2021 by the author. Licensee MDPI, Basel, Switzerland. This article is an open access article distributed under the terms and conditions of the Creative Commons Attribution (CC BY) license (https:// creativecommons.org/licenses/by/ $4.0 /)$.
Department of Medicine, Surgery and Dentistry "Scuola Medica Salernitana", University of Salerno, 84081 Baronissi, Italy; pmonteleone@unisa.it; Tel.: +39-089672833

Eating disorders (EDs), including anorexia nervosa, bulimia nervosa, binge-eating disorder and other less frequent syndromes [1], are complex psychiatric conditions characterized by abnormal eating or weight-control behaviors and body image preoccupation [2], which affect mainly adolescent and young adult females [3]. Although their etiology is still unknown and likely involves biological, psychological and environmental factors [4], stressful experiences are widely acknowledged to represent putative risk factors for their development and maintenance [5]. Thus, the endogenous stress response system is thought to play a pivotal role in the pathophysiology of EDs [6], and evidence of an altered functioning of both components of the body stress response system, namely the hypothalamus-pituitary-adrenal axis and the sympathetic nervous system, has been reported in ED patients [7-11]. Furthermore, deranged cortisol, sympathetic and emotional responses to psychosocial stressors have been detected in ED patients $[10,12]$, and this is consistent with the idea that an increased attentional bias toward social stimuli contributes to the pathophysiology of these disorders $[13,14]$.

The outbreak of the coronavirus disease 2019 (COVID-19) pandemic with the consequent adoption of social and physical distancing measures to contain virus transmission has involved people's exposure to different kinds of stressors, such as social isolation, impairment in the family and/or individual's economic condition, disruption in routinary activities and in everyday life and fear of being infected $[15,16]$. Because of such a stressful situation, while some stress-related reactions, such as concentration difficulties, irritability, insomnia and interpersonal conflicts, have arisen as physiological responses to the pandemic [17-19], a clear-cut increased prevalence of pathological anxiety and depression has occurred in the general population [20-22]. In line with this, people with a pre-existing psychiatric disorder have shown heightened vulnerability in terms of physical and mental distress [23-27], while people with EDs have displayed heightened food restriction, an increase in excessive physical exercising and more frequent binge/purging episodes as well as a worsening of other ED-specific and internalizing symptoms (namely anxiety, depression and post-traumatic stress symptoms) [28-32]. These data are corroborated by the observed increase during the pandemic in the number of urgent and routine referrals of individuals with EDs [33] as well as by the increase in in-patient admissions, especially of adolescents with EDs [34-36].

Several factors have been associated with the worsening of psychopathology induced by the COVID-19 pandemic in ED individuals. Heightened isolation, fear of contagion, reduced satisfaction with family and friends' relationships, reduced perceived social support and an increased exposure to aberrant routines and thin-related social media messages have been described as possible stress factors contributing to the deterioration of eatingspecific and general psychopathological symptoms in people with EDs [31,32,37]. Moreover, changes in treatment delivery have also occurred during the COVID-19 pandemic since the imposed restriction measures have implied reduced access to in-person treatment and an increase in online treatments [38-40]. Even if in some cases online treatment generated the patient's disappointment, since the therapeutic relationship was perceived as qualitatively 
unsatisfactory [38-42], in some others it allowed patients to maintain a therapeutic relationship [41] or to make treatment more accessible [41-43]. Thus, it has been demonstrated that the quality of the therapeutic relationship was inversely associated with the worsening of symptoms in ED people during the COVID-19 lockdown [32].

What can we learn from these COVID-19-related findings? First, the worsening of both ED-specific and general psychopathology during the stressful lockdown period supports the reliability of the hypothesized post-traumatic nature of ED symptomatology $[10,12,44]$ and provides novel and consistent evidence for the existence of a transdiagnostic vulnerability to acute stressful experiences, since the pandemic-induced worsening of psychopathology has been replicated across different psychiatric populations [45-47]. Second, the pandemic-induced impairment of general psychopathological symptoms (i.e., disturbed sleep, anxiety, depressive, post-traumatic, obsessive compulsive and panic symptoms) together with the worsening of ED-specific symptomatology further supports the idea of a re-conceptualization of ED psychopathology as a broad spectrum of mutual relationships among non-specific and ED-specific psychopathology $[48,49]$ and sustains the need for a personalized approach in the treatment of people with EDs as it is acknowledged for other psychiatric conditions [50]. Third, the data on COVID-19-induced changes in treatment delivery and the inverse association of patients' perception of the quality of telehealth medicine with the worsening of symptoms confirm the role of the therapeutic alliance as one of the most important resilience factors for individuals with EDs [51]. Fourth, the widespread implementation of internet-delivered psychological treatments induced by the COVID-19 pandemic [52,53], associated with the relatively positive attitudes toward e-therapies of people with EDs [54], corroborates the idea that, at least in some cases, telehealth therapies could be a promising opportunity to treat severe psychiatric disorders.

Funding: This research received no external funding.

Institutional Review Board Statement: Not applicable.

Informed Consent Statement: Not applicable.

Conflicts of Interest: The author declares no conflict of interest.

\section{References}

1. Monteleone, A.M.; Fernandez-Aranda, F.; Voderholzer, U. Evidence and perspectives in eating disorders: A paradigm for a multidisciplinary approach. World Psychiatry 2019, 18, 369-370. [CrossRef]

2. Stanghellini, G. Embodiment and the Other's look in feeding and eating disorders. World Psychiatry 2019, 18, 364-365. [CrossRef]

3. Treasure, J.; Duarte, T.A.; Schmidt, U. Eating disorders. Lancet 2020, 395, 899-911. [CrossRef]

4. Bulik, C.M.; Flatt, R.; Abbaspour, A.; Carroll, I. Reconceptualizing anorexia nervosa. Psychiatry Clin. Neurosci. 2019, 73, 518-525. [CrossRef]

5. Rojo, L.; Conesa, L.; Bermudez, O.; Livianos, L. Influence of stress in the onset of eating disorders: Data from a two-stage epidemiologic controlled study. Psychosom. Med. 2006, 68, 628-635. [CrossRef] [PubMed]

6. Chami, R.; Monteleone, A.M.; Treasure, J.; Monteleone, P. Stress hormones and eating disorders. Mol. Cell. Endocrinol. 2019, 497, 110349. [CrossRef]

7. Het, S.; Vocks, S.; Wolf, J.M.; Herpertz, S.; Wolf, O.T. Treatment-resistant blunted HPA activity, but reversible cardiovascular stress reactivity in young women with eating disorders. Front. Psychiatry 2020, 11, 726. [CrossRef] [PubMed]

8. Het, S.; Vocks, S.; Wolf, J.M.; Hammelstein, P.; Herpertz, S.; Wolf, O.T. Blunted neuroendocrine stress reactivity in young women with eating disorders. J. Psychosom. Res. 2015, 78, 260-267. [CrossRef]

9. Monteleone, A.M.; Monteleone, P.; Serino, I.; Amodio, R.; Monaco, F.; Maj, M. Underweight subjects with anorexia nervosa have an enhanced salivary cortisol response not seen in weight restored subjects with anorexia nervosa. Psychoneuroendocrinology 2016, 70, 118-121. [CrossRef]

10. Monteleone, A.M.; Cascino, G.; Ruzzi, V.; Pellegrino, F.; Carfagno, M.; Raia, M.; Maj, M. Multiple levels assessment of the RDoC "system for social process" in Eating Disorders: Biological; emotional and cognitive responses to the Trier Social Stress Test. J. Psychiat. Res. 2020, 130, 160-166. [CrossRef] [PubMed]

11. Monteleone, A.M.; Marciello, F.; Cascino, G.; Cimino, M.; Ruzzi, V.; Pellegrino, F.; Del Giorno, C.; Monteleone, P. Early traumatic experiences impair the functioning of both components of the endogenous stress response system in adult people with eating disorders. Psychoneuroendocrinology 2020, 115, 104644. [CrossRef] 
12. Monteleone, A.M.; Ruzzi, V.; Patriciello, G.; Cascino, G.; Pellegrino, F.; Vece, A.; Maj, M. Emotional reactivity and eating disorder related attitudes in response to the Trier Social Stress Test: An experimental study in people with Anorexia Nervosa and with Bulimia Nervosa. J. Affect. Disord. 2020, 274, 23-30. [CrossRef] [PubMed]

13. Cardi, V.; Mallorqui-Bague, N.; Albano, G.; Monteleone, A.M.; Fernandez-Aranda, F.; Treasure, J. Social difficulties as risk and maintaining factors in anorexia nervosa: A mixed-method investigation. Front. Psychiatry 2018, 9, 12. [CrossRef] [PubMed]

14. Monteleone, A.M.; Treasure, J.; Kan, C.; Cardi, V. Reactivity to interpersonal stress in patients with eating disorders: A systematic review and meta-analysis of studies using an experimental paradigm. Neurosci. Biobehav. Rev. 2018, 87, 133-150. [CrossRef] [PubMed]

15. Adhanom-Ghebreyesus, T. Addressing mental health needs: An integral part of COVID-19 response. World Psychiatry 2020, 19, 129-130. [CrossRef] [PubMed]

16. Wasserman, D.; Iosue, M.; Wuestefeld, A.; Carli, V. Adaptation of evidence-based suicide prevention strategies during and after the COVID-19 pandemic. World Psychiatry 2020, 19, 294-306. [CrossRef]

17. Galea, S.; Merchant, R.M.; Lurie, N. The mental health consequences of COVID-19 and physical distancing: The need for prevention and early intervention. JAMA Int. Med. 2020, 180, 817-818. [CrossRef]

18. Rooksby, M.; Furuhashi, T.; McLeod, H.J. Hikikomori: A hidden mental health need following the COVID-19 pandemic. World Psychiatry 2020, 19, 399-400. [CrossRef]

19. Vinkers, C.H.; van Amelsvoort, T.; Bisson, J.I.; Branchi, I.; Cryan, J.F.; Domschke, K.; Howes, O.D.; Manchia, M.; Pinto, L.; de Quervain, D.; et al. Stress resilience during the coronavirus pandemic. Eur. Neuropsychopharmacol. 2020, 35, 12-16. [CrossRef]

20. Brooks, S.K.; Webster, R.K.; Smith, L.E.; Woodland, L.; Wessely, S.; Greenberg, N.; Rubin, G.J. The psychological impact of quarantine and how to reduce: Rapid review of the evidence. Lancet 2020, 395, 912-920. [CrossRef]

21. Li, J.; Yang, Z.; Qiu, H.; Wang, Y.; Jian, L.; Ji, J.; Li, K. Anxiety and depression among general population in China at the peak of the COVID-19 epidemic. World Psychiatry 2020, 19, 249-250. [CrossRef]

22. Tyrer, P. COVID-19 health anxiety. World Psychiatry 2020, 19, 307-308. [CrossRef] [PubMed]

23. Stewart, D.E.; Appelbaum, P.S. COVID-19 and psychiatrists' responsibilities: A WPA position paper. World Psychiatry 2020, 19, 406-407. [CrossRef] [PubMed]

24. Unützer, J.; Kimmel, R.J.; Snowden, M. Psychiatry in the age of COVID-19. World Psychiatry 2020, 19, 130-131. [CrossRef] [PubMed]

25. Wang, Q.; Xu, R.; Volkow, N.D. Increased risk of COVID-19 infection and mortality in people with mental disorders: Analysis from electronic health records in the United States. World Psychiatry 2021, 20, 124-130. [CrossRef]

26. Marazziti, D.; Stahl, S.M. The relevance of COVID-19 pandemic to psychiatry. World Psychiatry 2020, 19, 261. [CrossRef]

27. De Hert, M.; Mazereel, V.; Detraux, J.; Van Assche, K. Prioritizing COVID-19 vaccination for people with severe mental illness. World Psychiatry 2021, 20, 54-55. [CrossRef]

28. Castellini, G.; Cassioli, E.; Rossi, E.; Innocenti, M.; Gironi, V.; Sanfilippo, G.; Felciai, F.; Monteleone, A.M.; Ricca, V. The impact of COVID-19 epidemic on eating disorders: A longitudinal observation of pre versus post psychopathological features in a sample of patients with eating disorders and a group of healthy controls. Int. J. Eat. Disord. 2020, 53, 1855-1862. [CrossRef]

29. Monteleone, A.M.; Marciello, F.; Cascino, G.; Abbate-Daga, G.; Anselmetti, S.; Baiano, M.; Balestrieri, M.; Barone, E.; Bertelli, S.; Carpiniello, B.; et al. The impact of COVID-19 lockdown and of the following "re-opening" period on specific and general psychopathology in people with eating disorders: The emergent role of internalizing symptoms. J. Affect. Disord. 2021, 285, 77-83. [CrossRef]

30. Monteleone, A.M.; Cascino, G.; Marciello, F.; Abbate-Daga, G.; Baiano, M.; Balestrieri, M.; Barone, E.; Bertelli, S.; Carpiniello, B.; Castellini, G.; et al. Risk and resilience factors for specific and general psychopathology worsening in people with Eating Disorders during COVID-19 pandemic: A retrospective Italian multicentre study. Eat. Weight Disord. 2021, 1, 3. [CrossRef]

31. Fernandez-Aranda, F.; Casas, M.; Claes, L.; Bryan, D.C.; Favaro, A.; Granero, R.; Gudiol, C.; Jiménez-Murcia, S.; Karwautz, A.; Le Grange, D.; et al. COVID-19 and implications for eating disorders. Eur. Eat. Disord. Rev. 2020, 28, 239-245. [CrossRef] [PubMed]

32. Machado, P.P.P.; Pinto-Bastos, A.; Ramos, R.; Rodrigues, T.F.; Louro, E.; Gonçalves, S.; Brandão, I.; Vaz, A. Impact of COVID-19 lockdown measures on a cohort of eating disorders patients. J. Eat. Disord. 2020, 8, 57. [CrossRef] [PubMed]

33. Richardson, C.; Patton, M.; Phillips, S.; Paslakis, G. The impact of the COVID-19 pandemic on help-seeking behaviors in individuals suffering from eating disorders and their caregivers. Gen. Hosp. Psychiatry 2020, 67, 136-140. [CrossRef]

34. Haripersad, Y.V.; Kannegiesser-Bailey, M.; Morton, K.; Skeldon, S.; Shipton, N.; Edwards, K.; Newton, R.; Newell, A.; Stevenson, P.G.; Martin, A.C. Outbreak of anorexia nervosa admissions during the COVID-19 pandemic. Arch. Dis. Child. 2021, 106, e15. [CrossRef] [PubMed]

35. Schwartz, M.D.; Costello, K.L. Eating disorder in teens during the covid-19 pandemic. J. Adolesc. Health 2021, 68, 1022. [CrossRef] [PubMed]

36. Solmi, F.; Downs, J.L.; Nicholls, D.E. COVID-19 and eating disorders in young people. Lancet Child Adolesc. Health $2021,5,316-318$. [CrossRef]

37. McCombie, C.; Austin, A.; Dalton, B.; Lawrence, V.; Schmidt, U. “Now it's just old habits and misery"-understanding the impact of the covid-19 pandemic on people with current or life-time eating disorders: A qualitative study. Front. Psychiatry 2020, 11, 589225. [CrossRef] 
38. Schlegl, S.; Meule, A.; Favreau, M.; Voderholzer, U. Bulimia nervosa in times of the COVID-19 pandemic-Results from an online survey of former inpatients. Eur. Eat. Disord. Rev. 2020, 28, 847-854. [CrossRef]

39. Schlegl, S.; Maier, J.; Meule, A.; Voderholzer, U. Eating disorders in times of the COVID-19 pandemic-Results from an online survey of patients with anorexia nervosa. Int. J. Eat. Disord. 2020, 53, 1791-1800. [CrossRef]

40. Brown, S. Perinatal mental health and the COVID-19 pandemic. World Psychiatry 2020, 19, 333-334. [CrossRef]

41. Vuillier, L.; May, L.; Greville-Harris, M.; Surman, R.; Moseley, R.L. The impact of the COVID-19 pandemic on individuals with eating disorders: The role of emotion regulation and exploration of online treatment experiences. J. Eat. Disord. 2021, 9, 1-18. [CrossRef]

42. Frayn, M.; Fojtu, C.; Juarascio, A. COVID-19 and binge eating: Patient perceptions of eating disorder symptoms; tele-therapy; and treatment implications. Curr. Psychol. 2021, 40, 6249-6258. [CrossRef] [PubMed]

43. Shaw, H.; Robertson, S.; Ranceva, N. What was the impact of a global pandemic (COVID-19) lockdown period on experiences within an eating disorder service? A service evaluation of the views of patients, parents/carers and staff. J. Eat. Disord. 2021, 9, 14. [CrossRef]

44. Trottier, K.; MacDonald, D.E. Update on psychological trauma; other severe adverse experiences and eating disorders: State of the research and future research directions. Curr. Psychiatry Rep. 2017, 19, 45. [CrossRef] [PubMed]

45. Fusar-Poli, P.; Solmi, M.; Brondino, N.; Davies, C.; Chae, C.; Politi, P.; Borgwardt, S.; Lawrie, S.M.; Parnas, J.; McGuire, P. Transdiagnostic psychiatry: A systematic review. World Psychiatry 2019, 18, 192-207. [CrossRef] [PubMed]

46. Barlow, D.H.; Harris, B.A.; Eustis, E.H.; Farchione, T.J. The unified protocol for transdiagnostic treatment of emotional disorders. World Psychiatry 2020, 19, 245-246. [CrossRef]

47. McIntyre, R.S.; Lee, Y. Preventing suicide in the context of the COVID-19 pandemic. World Psychiatry 2020, 19, 250-251. [CrossRef]

48. Gross, J.J.; Uusberg, H.; Uusberg, A. Mental illness and well-being: An affect regulation perspective. World Psychiatry 2019, 18, 130-139. [CrossRef]

49. Monteleone, A.M.; Cascino, G. A systematic review of network analysis studies in eating disorders: Is time to broaden the core psychopathology to non specific symptoms. Eur. Eat. Disord. Rev. 2021, 29, 531-547. [CrossRef]

50. Barber, J.P.; Solomonov, N. Toward a personalized approach to psychotherapy outcome and the study of therapeutic change. World Psychiatry 2019, 18, 291-292. [CrossRef]

51. Graves, T.A.; Tabri, N.; Thompson-Brenner, H.; Franko, D.L.; Eddy, K.T.; Bourion-Bedes, S.; Brown, A.; Constantino, M.J.; Flückiger, C.; Forsberg, S.; et al. A meta-analysis of the relation between therapeutic alliance and treatment outcome in eating disorders. Int. J. Eat. Disord. 2017, 50, 323-340. [CrossRef]

52. Andersson, G.; Titov, N.; Dear, B.F.; Rozental, A.; Carlbring, P. Internet-delivered psychological treatments: From innovation to implementation. World Psychiatry 2019, 18, 20-28. [CrossRef] [PubMed]

53. Torous, J.; Andersson, G.; Bertagnoli, A.; Christensen, H.; Cuijpers, P.; Firth, J.; Haim, A.; Hsin, H.; Hollis, C.; Lewis, S.; et al. Towards a consensus around standards for smartphone apps and digital mental health. World Psychiatry 2019, 18, 97-98. [CrossRef] [PubMed]

54. Linardon, J.; Shatte, A.; Tepper, H.; Fuller-Tyszkiewicz, M. A survey study of attitudes toward; and preferences for; e-therapy interventions for eating disorder psychopathology. Int. J. Eat. Disord. 2020, 53, 907-916. [CrossRef] [PubMed] 